\title{
Algoritma Fast Corner Detection dan Natural Feature Tracking Media Tumbuhan Berbasis Augmented Reality
}

\author{
Aldy Febriyandani ${ }^{1}$, Fauziah ${ }^{2}$, Ira Diana Sholihati ${ }^{3}$ \\ ${ }^{3}$ Informatika, Fakultas Teknologi Komunikasi dan Informatika, Universitas Nasional \\ e-mail: *ªldifangky@gmai.l.com, ${ }^{2}$ fauziah@ civitas.unas.ac.id, ${ }^{3}$ iradiana2803@ gmail.com
}

\begin{abstract}
Abstrak
Kemajuan teknologi dimasa sekarang sangatlah pesat, Salah satunya dalam bidang media pembelajaran atau edukasi.Teknologi Augmented Reality (AR) Merupakan sebuah penggabungan dari digital konten yang telah di buat di komputer dari dengan dunia nyata.Penelitian ini bertujuan untuk memberi pengenalan tentang tumbuhan sehingga dapat mengetahui informasi tentang tanaman tersebut. Penelitian ini menggunakan sebuah metode yaitu natural feature tracking serta menggunakan sebuah sistem pengembangan yaitu MDLC( Multimedia Development Life Cycle) dan memakai algoritma Fast Corner Detection dan Natural Feature Tracking, Sehingga menghasilkan sebuah aplikasi yang dapat menampilkan objek $3 D$ tentang tumbuhan, dan terdapat penjelasan singkat mengenai tumbuhan, Aplikasi ini dapat menggunakan sistem operasi Android, Pengujian aplikasi menggunakan 3 handphone android yaitu Samsung A2018 dengan versi andorid 9,Oppo A9 2019 dan Samsung A51 2020 bahwa pada saat kemiringan $<18^{\circ}$ ketiga handphone tersebut tidak mendeteksi marker sedangkan saat pada sudut $20^{\circ}-60^{\circ}$ dan $61^{\circ}-90^{\circ}$ ketiga handphone tersebut dapat mendeteksi dan terbaca pada layar handphone.
\end{abstract}

Kata kunci- Augmented Reality, Multimedia Development Life Cycle, Algoritma Fast Corner Detection dan Nautral Feature Tracking.

\begin{abstract}
Technological advances today are very rapid, one of which is in the field of learning media or education. Augmented Reality (AR) Technology is an amalgamation of digital content that has been created on a computer from the real world. This study aims to provide an introduction to plants so that they can find out information about the plant. This study uses a method, namely natural feature tracking and uses a development system, namely MDLC (Multimedia Development Life Cycle) and uses Fast Corner Detection and Natural Feature Tracking algorithms, resulting in an application that can display $3 D$ objects about plants, and there is a brief explanation of plants, This application can use the Android operating system, Testing the application using 3 android phones, namely Samsung A2018 with android version 9, Oppo A9 2019 and Samsung A51 2020 that when the slope is $<18^{\circ}$ the three cellphones do not detect the marker while at an angle of $20^{\circ}-60^{\circ}$ and $61^{\circ}-90^{\circ}$ the three mobile phones can detect and be read on the mobile screen.
\end{abstract}

Keywords - Augmented Reality, Multimedia Development Life Cycle, Algoritma Fast Corner Detection dan Nautral Feature Tracking. 


\section{PENDAHULUAN}

$\mathrm{T}$ umbuhan merupakan makhluk hidup yang diciptakan oleh Allah yang dapat hidup berdampingan dengan manusia.Tumbuhan juga dapat menghasilkan makanan sendiri dengan melakukan proses fotosintesis, Tumbuhan itu sendiri dapat menghasilkan oksigen $\left(\mathrm{O}_{2}\right)$ mengubah Karbondioksida $\left(\mathrm{CO}_{2}\right)$, Oksigen tersebut digunakan untuk bernafas makhluk hidup lainya.Sangat penting tumbuhan untuk kelangsungan hidup manusia dan bumi, Karena tumbuhan memiliki peran sebagai penghasil oksiden $\left(\mathrm{O}_{2}\right)$ jika dibumi memiliki sedikit tumbuha akan menyebabkan bencana alam dan kurangnya oksigen bagi makhluk hidup.[1]

Informasi sudah mudah didapatkan dengan menggunakan smartphone melalui internet, smartphone ialah suatu alat komunikasi yang sudah mendukung teknologi Augmented Reality.Augmented Reality sangat berguna, untuk sebagai media pengenalan dengan lebih mudah, karena pengenalan dapat berapa bentuk 2 dimensi dan 3 dimensi sehingga lebih dapat menarik perhatian masyarakat.[2]

Augmented Reality dapat digunakan sebagai media pengenalan mengenai tumbuhan dengan object 3D menggunakan Algoritma fast corner yang sudah disediakan oleh Vuforia, Vuforia itu sendiri merupakan software free yang dapat digunakan untuk membuat Augmented Reality dan di dalam Vuforia dapat mengeluarkan rating 1-5 dimana semakin rendah rating tersebut maka gambar tersebut akan susah dibaca oleh kamera smartphone dan sedangkan semakin tinggi rating gambar tersebut maka gambarnya akan mudah dibaca oleh smartphone.

Pada penelitian serupa yang telah di lakukan dengan judul Pengembangan Media Pembelajaran Berbasis Augmeted Reality yang bertujuan untuk membuat pembelarajan yang efektif, mudah di peroleh, serta penggunaanya yang mudah dengan memanfaatkan teknologi augmented reality [3]. Penelitian serupa juga di lakukan yang berjudul Rancangan Bangun Aplikasi Augmented Reality Untuk Deteksi Pengenalan Tanaman Obat Berbasis Android yang bertujuan untuk pengenalan tanaman obat [4]. Pada penelitian terkait juga di lakukan penelitian menggunakan Algoritma fast corner dengan judul Augmeted Reality Sebagai Media Pembelajaran Perangkat Keras Komputer Dengan Fast Corner Dan Catural Feature Tracking pada aplikasi ini bertujuan untuk memperkenalkan komponen komponen komputer dengan bentuk dengan memanfaatkan augmented reality dan menggunakan [5]. Penelitian serupa di lakukan dengan menggunakan algoritma Features from Accelerated Segment Test (FAST) dengan judul Augmented Marker Based Tracking Visualisasi Drawing 2D Dalam Bentuk 3D Dengan Metode Fast Corner Detection tujuan aplikasi ini di buat untuk pembelajaran penggambaran 2D ke bentuk 3D atau sebaliknya [6]. Penelitian terkait juga di lakukan dengan judul Augmented Reality Struktur Dan Fungsi Tumbuhan Sebagai Media Pembelajaran Berbasis Platform Andorid aplikasi ini di buat untuk sebagai media pembelajaran tentang stkruktur dan fungsi tumbuhan [7]. Penerapan augmented reality sebagai media pengenalan telah di lakukan penelitian yang berjudul Aplikasi Natural Pengenalan Tanaman Berbasis Augmented Reality Pada Perangkat Android aplkiasi tersebut di buat bertujuan untuk memberikan informasi tentang tanaman memanfaatkan sebuah teknologi augmented reality dengan sistem operasi android [8]. Algoritma fast corner detection juga di gunakan pada di penelitian yang berjudul Aplikasi Augmented Reality (AR) Dengan Metode Based Tracker Sebagai Media Pengenalan Hewan Darat Pada Anak Usia Dini Menggunakan Algoritma Fast Corner Detection [9].

Dari penguraian di atas, peneliti ingin menciptakan suatu aplikasi yang memanfaatkan teknolgi augmented reality sebagai media pengenalan tumbuhan yang akan dapat membatu dalam mempelajari tumbuhan dengan bentuk object 3D yang nantinya akan dapat terlihat dengan jelas bentuk dari tanaman dan disertai dengan informasi, Karena di Indonesia sedang menjalani wabah pandemi corona sehingga memberikan dampak yang sangat besar dalam bidang ilmu

Aldy,et., al [Algoritma Fast Corner Detection dan Natural Feature Tracking Media Tumbuhan Berbasis Augmented Reality] 
pengetauhan, banyak tempat wisata yang di tutup supaya tidak mengundang kerumunan dan menyebabkan kurangnya informasi dan pengetahuan yang diketauhi

\section{METODE PENELITIAN}

\subsection{Unity}

Unity adalah suatu aplikasi gratis yang dapat digunakan untuk membuat sebuah aplikasi berbasis 2 dimensi atau 3 dimensi, Unity sendiri mendukung banyak platform seperti PC, Android, WebGL, Ios, TvOS, Xbox One, Ps Vita, PS4, Facebook. [11]

\subsection{Augmented Reality}

Sebuah teknologi yang dapat mebantu manusia dalam memvisualisasi objek 2D maupun 3D ke lingkungan sebeneranya dalam waktu yang nyata [10]

\subsection{Vuforia}

Vuforia di pakai membuat sebuah aplikasi berasis augmented reality .Voforia menggunakan teknologi penglihatan untuk mengenali gambar secara real time dan 3D object. sehingga di layar handphone bisa menampilkan dunia nyata dan dunia yang di buat di aplikasi tesebut. [5]

\subsection{Kebutuhan Sistem}

Dalam membuat aplikasi penulis membutuhkan hardware dan software di yang telah di jabarkan pada tabel 1 dan 2 .

Tabel 1. Hardware yang Digunakan

\begin{tabular}{|l|l|}
\hline Perangkat & Kuantitas \\
\hline Motherboard & Astock B450 \\
\hline Processor & $\begin{array}{l}\text { AMD Rayzen 5 } \\
\text { 3500x }\end{array}$ \\
\hline GPU & RTX 2060 6GB \\
\hline Ram & 16 GB \\
\hline SSD & 1 TB \\
\hline
\end{tabular}

Tabel 2. Software yang Digunakan

\begin{tabular}{|l|}
\hline Software \\
\hline Unity \\
\hline SketchUp 2020 \\
\hline Adobe Photoshop \\
\hline
\end{tabular}




\subsection{Multimedia Development Life Cycle(MDLC)}

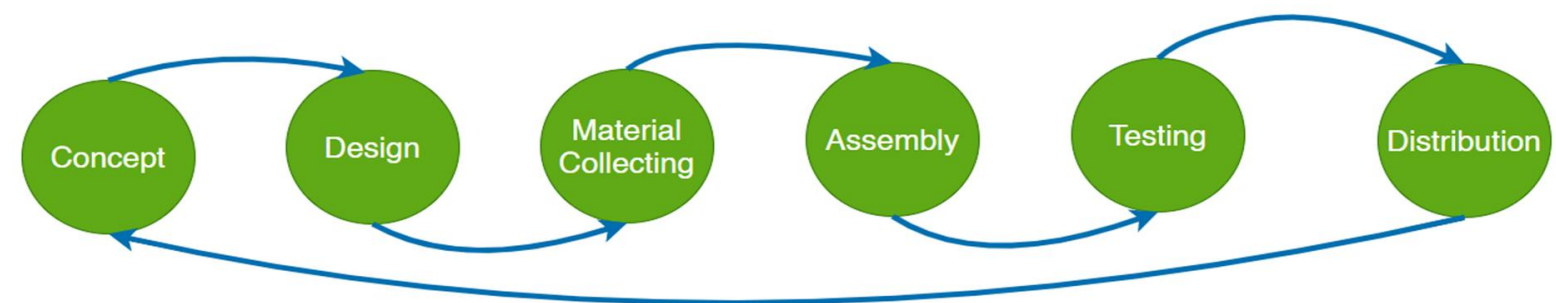

Gambar 1. MDLC Model

Penelitian menggunakan metode Multimedia Development Life Cycle. Terdapat 6 tingkatan dalam proses pembuatan apliaksi yaitu concept, design, material collecting, assembly, testing dan distribution.

1. Concept

Merupakan sebuah konsep pertama dari membuat aplikasi virual reality, Pada tahapan untuk menentukan tujuan untuk siapa aplikasi ini akan di gunakan.

2. Design

Design adalah tahapan pembuatan rancangan antar muka (interface).

3. Material Collecting

Bertujuan untuk mengumpulkan bahan yang akan di gunakan, Seperti infromasi yang akan di sampaikan, design 3D setiap objek.

4. Assenbly

Tahap ini adalah semua bahan yang akan di gunakan di gabung seperti design, objeck 3D, Unity 3D sehingga mejadi sebuah aplikasi.

5. Testing

Testing di lakukan untuk menguji aplikasi yang di buat sudah sesuai, dan memastikan tidak ada nya bug pada aplikasi .

6. Distribution

Pada tahap ini akan di bagikan atau di gunakan untuk menyapaikan informasi sesuai dengan tujuan dari aplikasi.

\subsection{Fast Corner Detection}

Sebuah algoritma yang bekerja melacak sudut-sudut pada object. Bertujuan untuk menunjukkan presisi dari setiap titik sudut dan memiliki kinerja perhitungan yang tinggi dan efisien dalam pendeteksian suatu objek dan pelacakan suatu objek [5]

Aturan di algoritma menetapkan titik pada sudut dengan titik sudut $\mathrm{p}$ yang akan di masukkan data dengan 16 piksel pata titik p.Contoh pada gambar 2 yaitu menentukan pada setiap masing-masing.perbedaan, yaitu

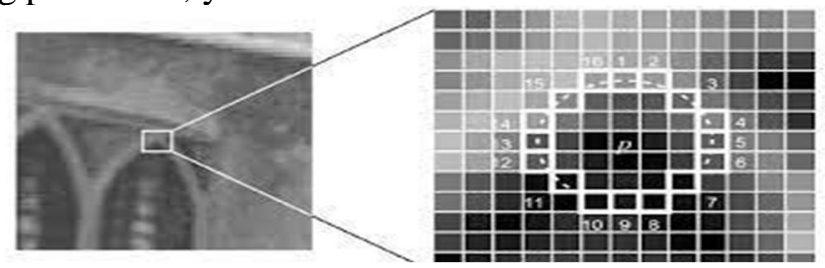

Gambar 2. Kerja Citra dan di Titik p

$\mathrm{I}<\mathrm{I} p$-tgelap

$\mathrm{C}=\left\{\mathrm{I}_{p}+t<\mathrm{I}_{n}<\mathrm{I}_{p}+\right.$ tnormal

$\mathrm{I}_{p}-t<\mathrm{I}_{p}-t<\mathrm{I}$ pterang

Aldy,et., al [Algoritma Fast Corner Detection dan Natural Feature Tracking Media Tumbuhan Berbasis Augmented Reality] 


\subsection{Natural Feature Tracking}

Natural Feature Tracking yang sering disebut juga NFT merupakan suatu metode yang di gunakan di augmented reality yang bertujuan untuk mendeteksi dan melacak secara alami pada gambar itu sendiri, Dalam library vufforia terdapat Natural Feature Tracking yang memiliki fungsi untuk menandai gambar yang bersumber pada pola poin sudut yang ada pada gambar [12].

\subsection{Marker}

Marker merupakan sebuah wujud yang sudah di bentuk kedalam gambar,Marker ini menjadi sebuah penanda yang ada di Augmented Reality [12]

\subsection{Rancangan Flowchart Augmented Reality}

Flowchart di gunakan untuk menggambarkan step by step pada perancangan suatu aplikasi, Berfunsi untuk membuat cara penggunaan yamg di pilih maka dapat melihat cara penggunaan aplikasi ini supaya mengerti cara menjalankan aplikasi ini dengan baik.

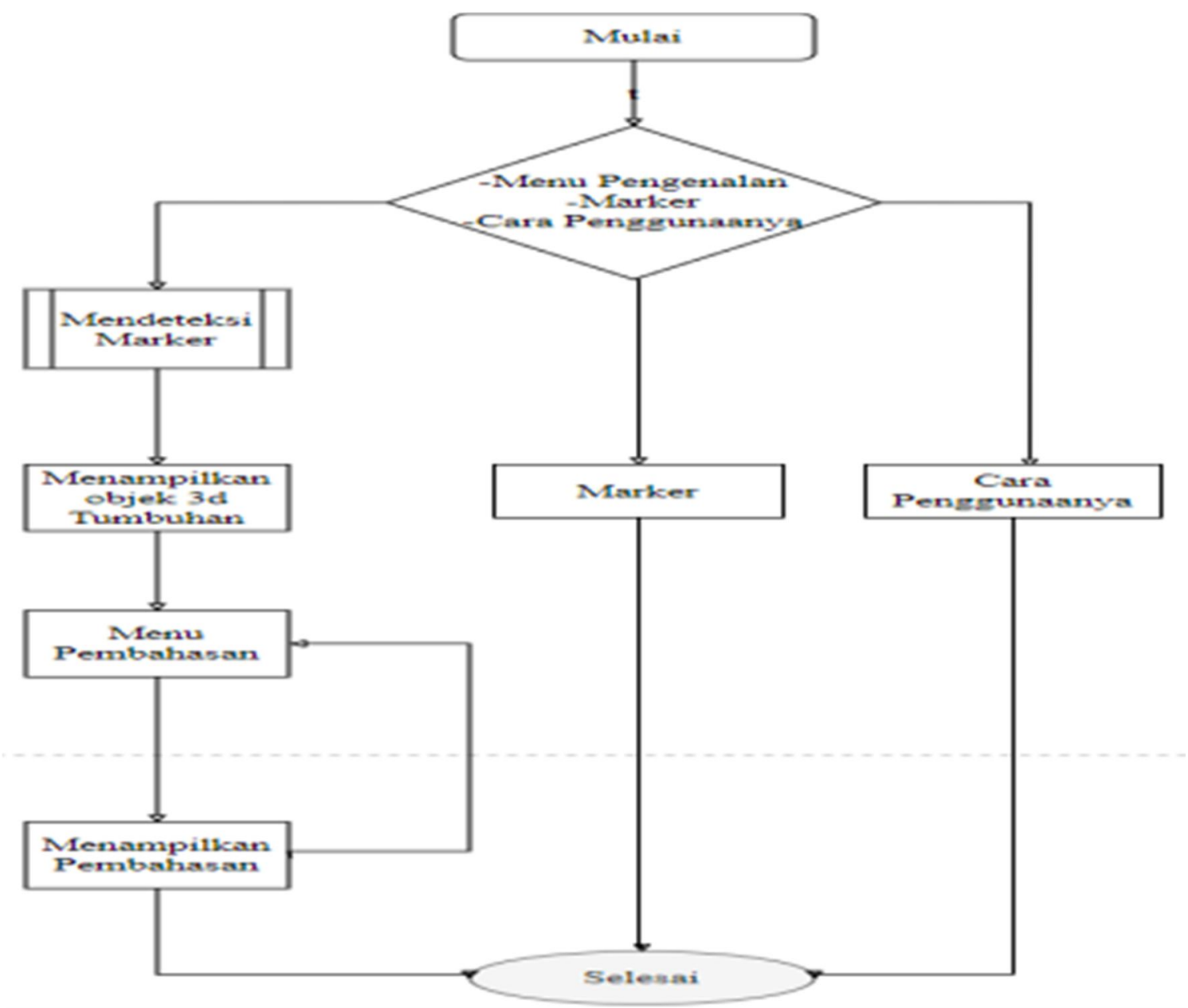

Gambar 3. Flowchart Penelitian

Pada gambar 3 menjelaskan alur dari aplikasi. Saat aplikasi sedang di gunakan maka tampilan pertama dari aplikasi tersebut adalah tampilan menu. Menu tersebut terdapat pilihan yaitu menu pengenalan, menu marker dan menu cara penggunaanya. 
Ketika menu yang dipilih yaitu menu pengenalan maka proses selanjutnya yaitu menu marker. Ketika berhasil di scan marker, maka akan menampilkan object 3D dari sistem pengenalan tumbuhan. jika sudah muncul objectnya lalu akan ada pilihan button untuk penjelesan dari tumbuhan yang ingin diketahui, misal tumbuhan ralesia maka tekan button raflesia nanti akan ada penjelasan tentang tumbuhan tersebut.Menu marker dipilih supaya menampilkan marker yang sudah di setting di vuforia dan bisa juga di download. Menu cara penggunaan di pilih maka dapat melihat cara penggunaan aplikasi ini supaya mengerti cara menjalankan aplikasi ini dengan.

\section{HASIL DAN PEMBAHASAN}

\subsection{Flowchart}

Berikut merupakan alur yang di gunakan pada aplikasi pengenalan tumbuhan berbasis augmented reality

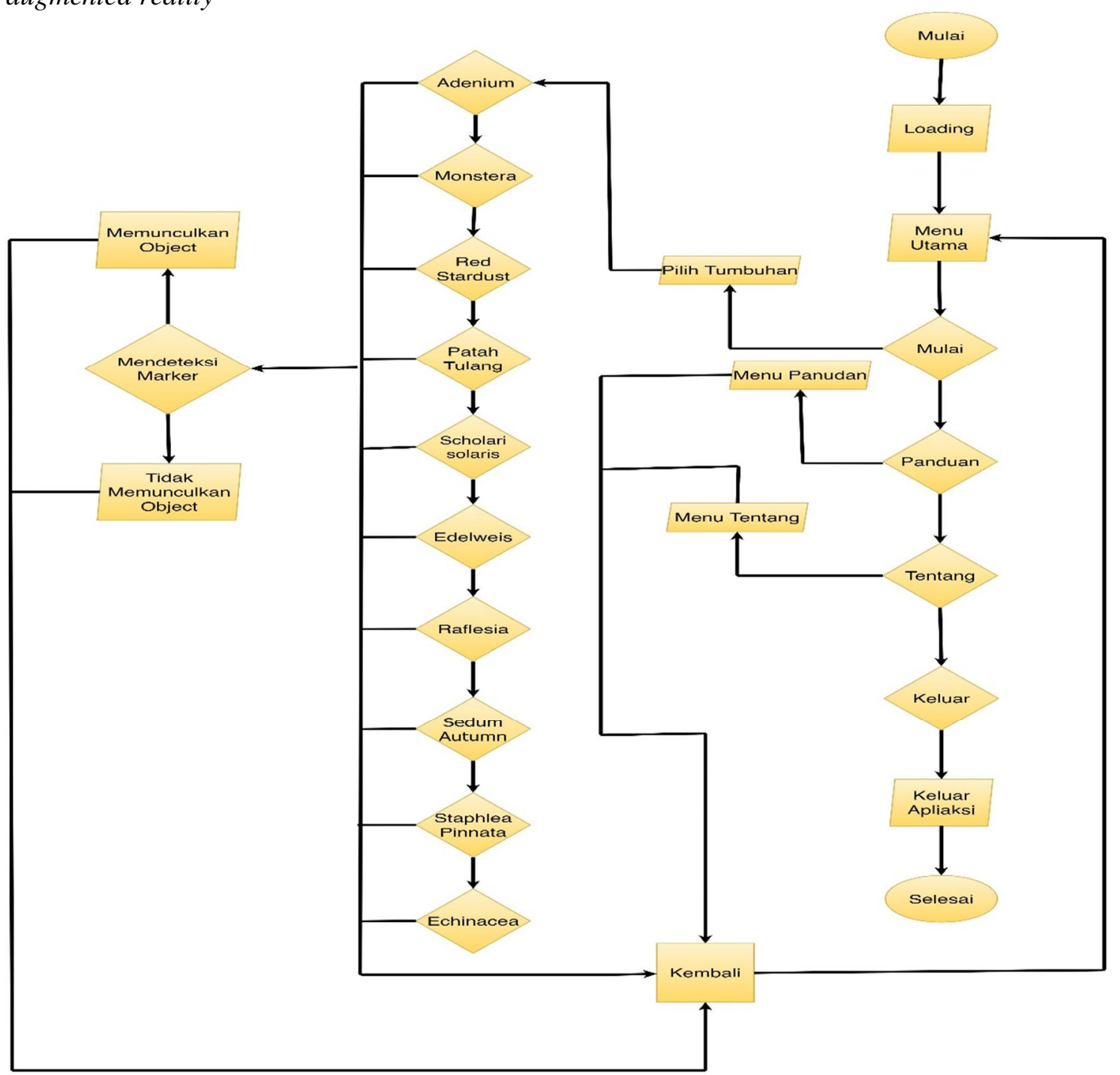

Gambar 4. Flowchart pada Aplikasi

Aldy,et., al [Algoritma Fast Corner Detection dan Natural Feature Tracking Media Tumbuhan Berbasis Augmented Reality] 
Pada gambar 4 menunjukan sebuah alur dari aplikasi pengenalan tumbuhan yang telah dibuat terdiri dari loading, menu utama, Pada menu utama terdapat empat pilihan yaitu menu , tentang, penduan, dan keluar. Jika kita memilih panduan akan memberikan panduan cara memakai aplikasi tersebut dan dapat mendownload marker pada menu tersebut, Jika memilih tentang akan menampilkan pengenalan tentang aplikasi tersebut dan nama pembuat aplikasi tersebut sedangkan jika memilih menu akan menampilkan pilihan tanaman yang terdiri dari adenium , monstera, redstardust, patah tulang, scolarisolaris, edelweis, reflesia, sedum autumn, stephylea pinnata, dan echinacea, setelah memilih satu dari sepuluh tumbuhan akan menampilkan penjelasan tenang tumbuhan tersebut dan mengscan marker dan menampilkan object $3 \mathrm{~d}$.

\subsection{Fast Corner Detection}

Pada gambar 5 terdapat titik pusat $\mathrm{p}$ pada posisi awalan (xp, xy) yang telah di tunjuk oleh vuforia engine, Setelah itu vuforia memilih 4 titik pusat pada gambar $(n=1)$ yang terletak pada titik pusat $(x p, y p+3),(n=2)$ terletak titik pusat $(x p+3, y p),(n=3)$ terletak titik pusat $(x p, y p-3)$, $(n=4)$ terletak titik pusat $(x p-3, y p)$
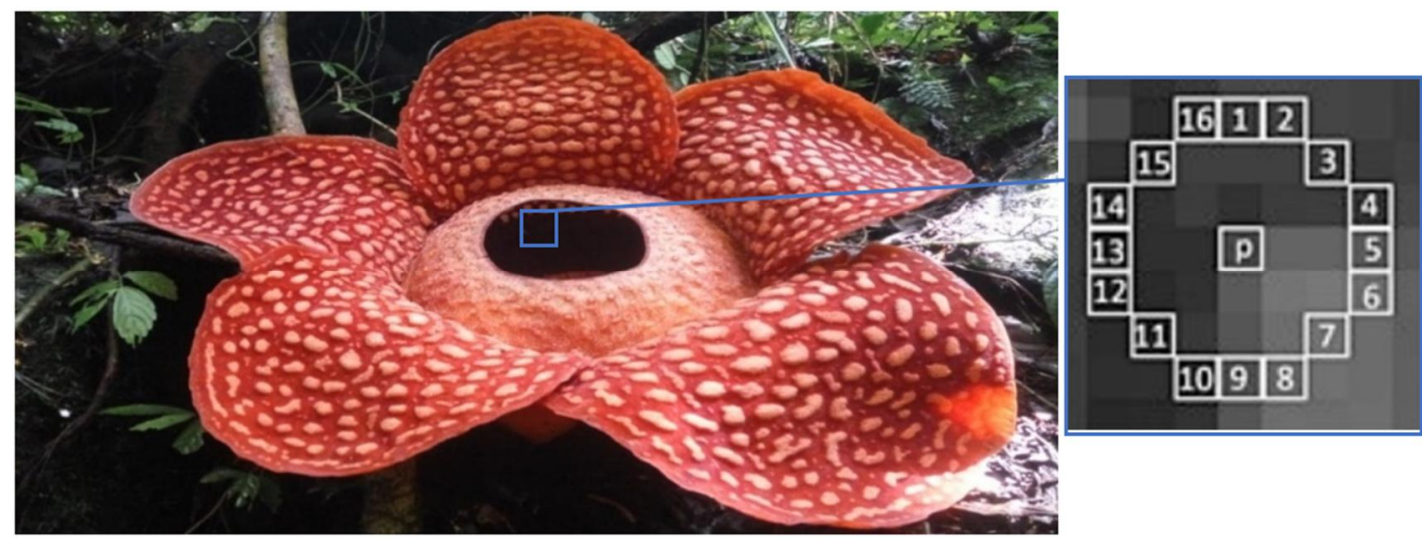

Gambar 5. Rafleisa Sumber: google.com

\subsection{Penerapan Natural Feature Tracking}

Tabel 3. Natural Feature Tracking

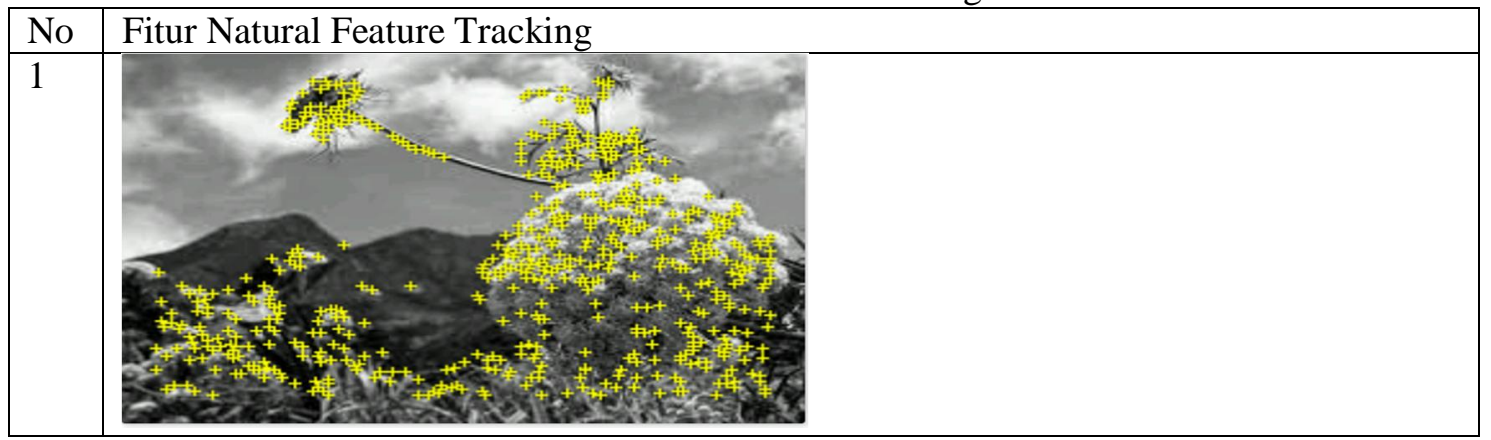

Aldy,et., al [Algoritma Fast Corner Detection dan Natural Feature Tracking Media Tumbuhan Berbasis Augmented Reality] 
ISSN 2407-4322

Vol. 8, No. 3, September 2021, Hal. 1062-1076

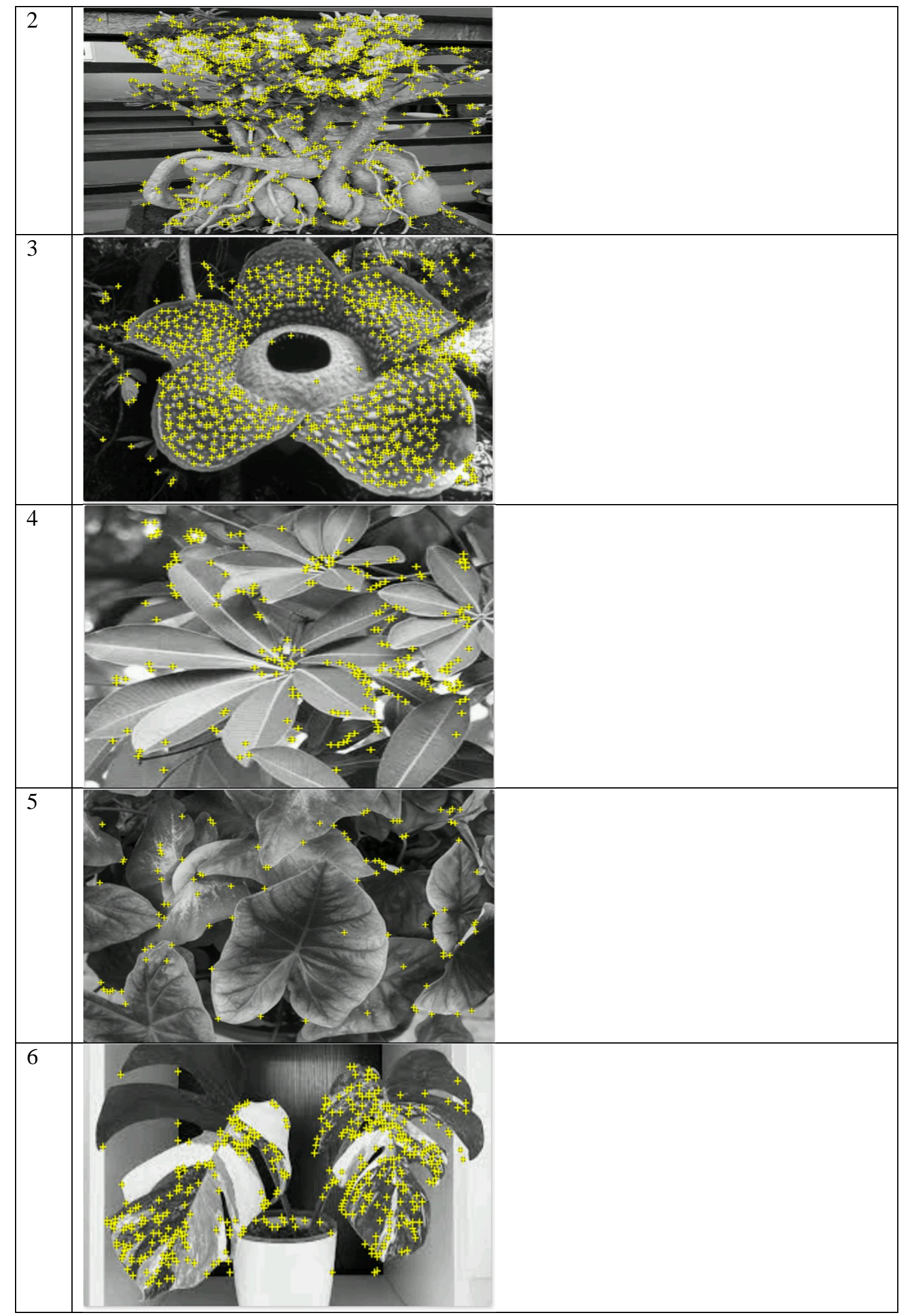

Aldy,et., al [Algoritma Fast Corner Detection dan Natural Feature Tracking Media Tumbuhan Berbasis Augmented Reality] 


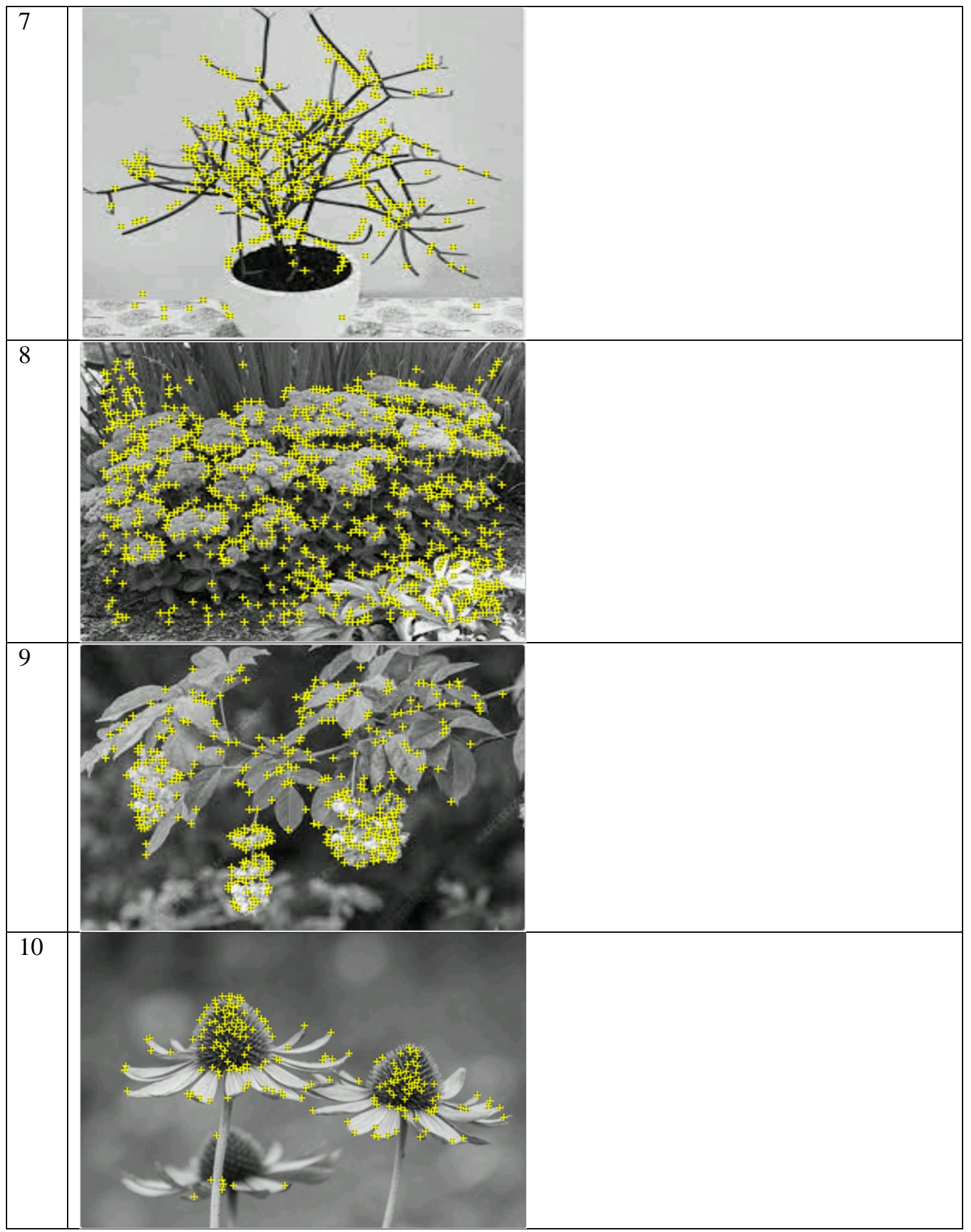

Pada tabel 3 menampilkan fitur Natural Feature Tracking yang sudah tersedia divoforia engine dan memiliki fungsi untuk menandai gambar yang bersumber pada pola poin sudut yang ada pada gambar. 


\subsection{Penerapan User Interface}

Tabel 4. Hasil User Interface

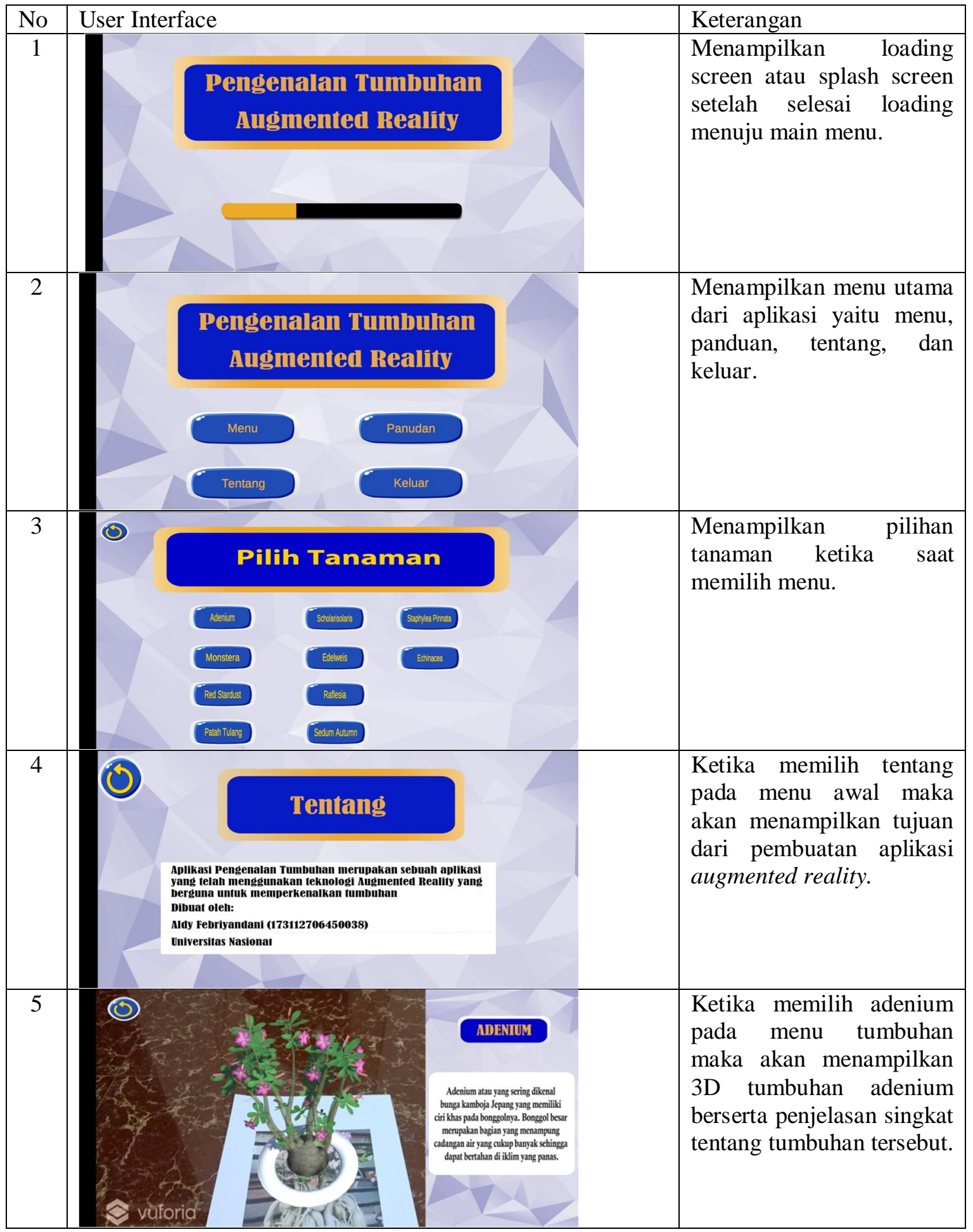

Aldy,et., al [Algoritma Fast Corner Detection dan Natural Feature Tracking Media Tumbuhan Berbasis Augmented Reality] 


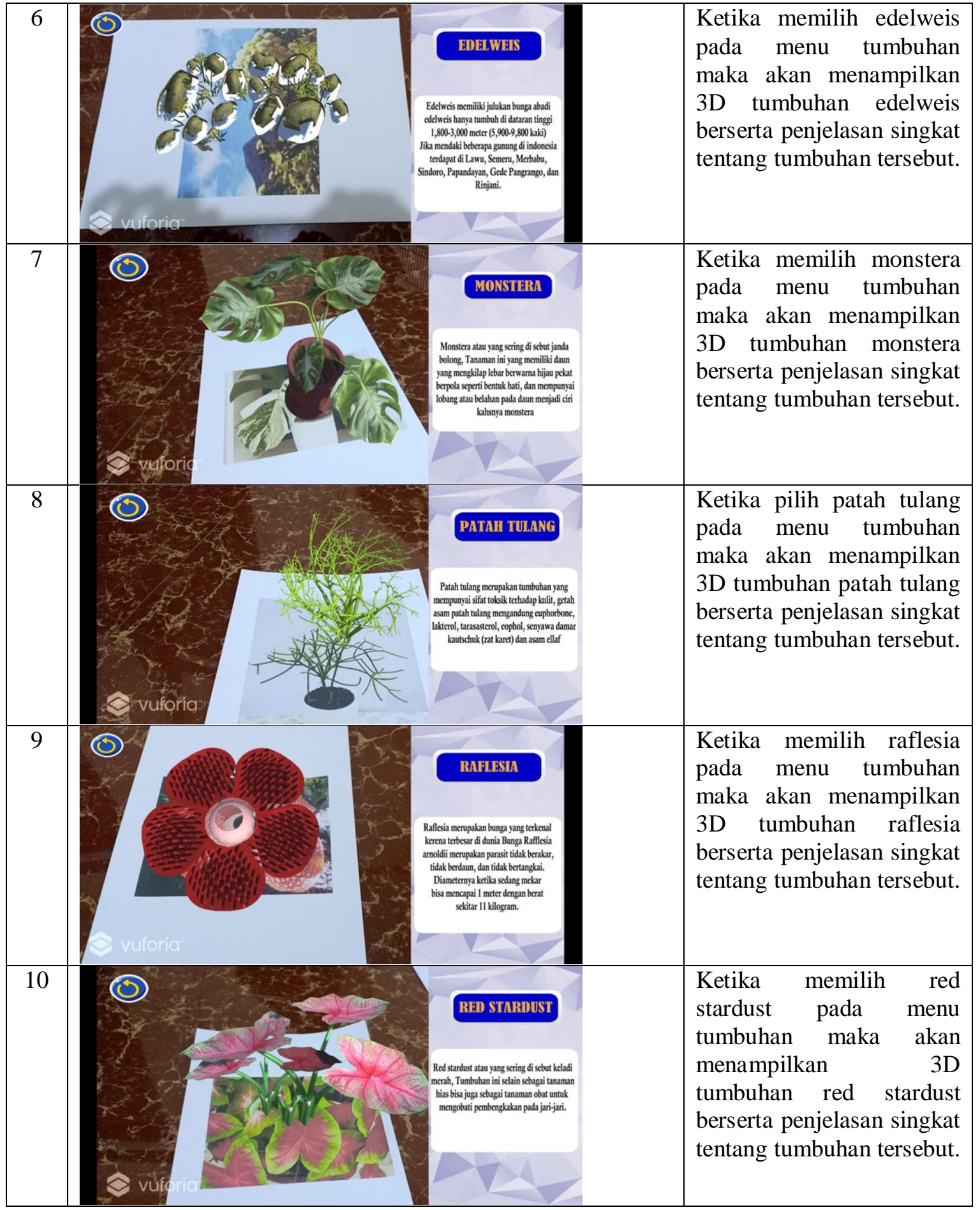




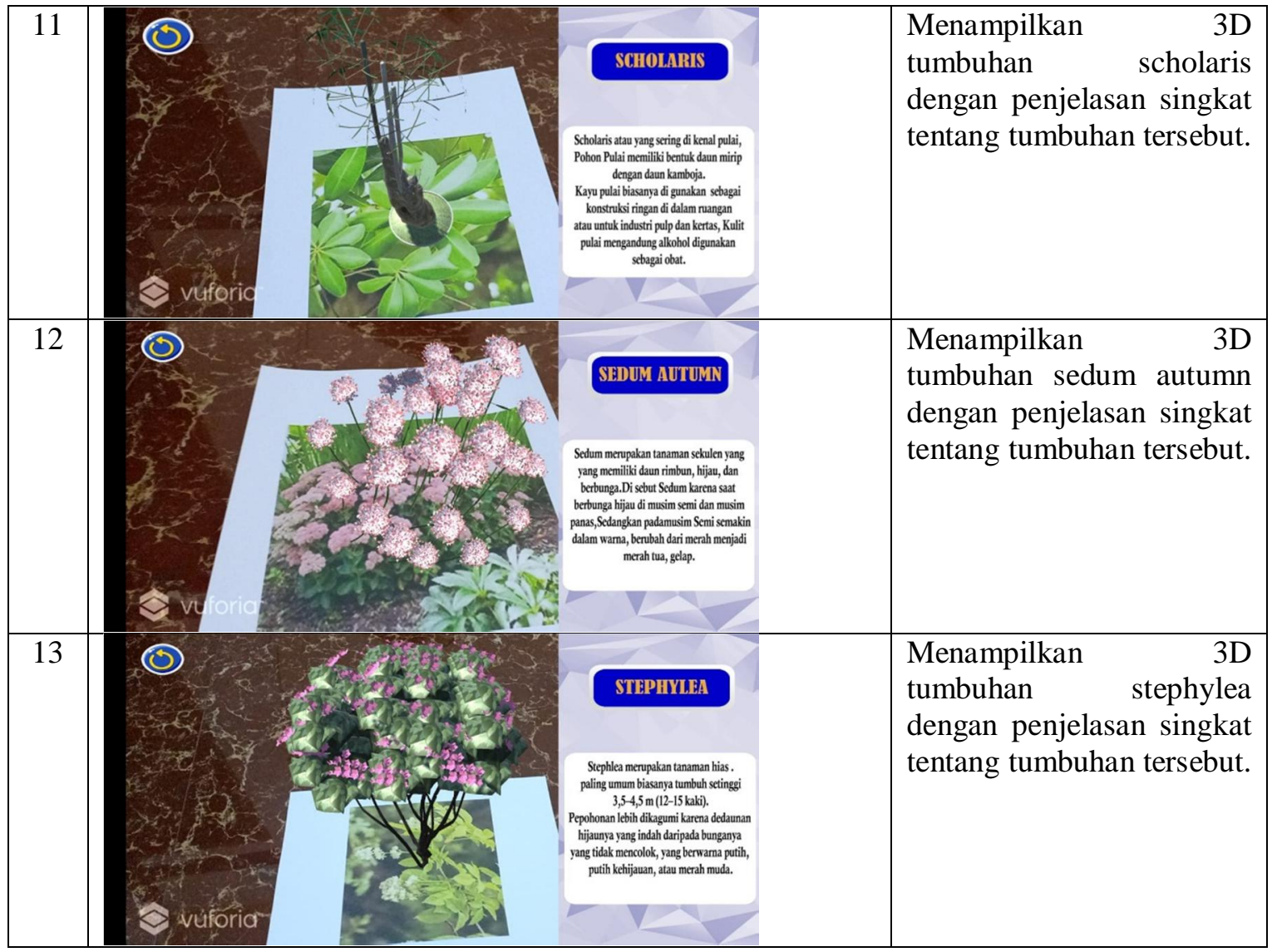

\subsection{Pengujian Aplikasi}

Pengujian di laksanakan di beberapa hanphone android dengan versi android yang berbeda - beda, mendapatkan hasil sebagai berikut:

Tabel 5. Handphone yang Digunakan

\begin{tabular}{ll}
\hline Perangkat & Model \\
\hline Samsung A7 2018 & $9.0($ Pie $)$ \\
Oppo A9 2019 & $10.0(\mathrm{Q})$ \\
Samsung A51 2020 & $11.0(\mathrm{R})$ \\
\hline
\end{tabular}

Pada tabel 5 merupakan handphone yang dipakai suntuk pengujian aplikasi, handphone tersebut terdapat versi yang berbeda beda bertujuan untuk membandingkan tiap handphone sudah sesuai atau belum, pada handphone tersebut.

\subsection{Hasil Pengujian Jarak Minimal}

Tabel 6. Hasil Pengujian Jarak Minimal

\begin{tabular}{lll}
\hline Perangkat & Model & Jarak Minimal \\
\hline Samsung A7 2018 & $9.0($ Pie $)$ & $+10 \mathrm{Cm}$ \\
Oppo A9 2019 & $10.0(\mathrm{Q})$ & $+10 \mathrm{Cm}$ \\
Samsung A51 2020 & $11.0(\mathrm{R})$ & $+10 \mathrm{Cm}$ \\
\hline
\end{tabular}


Setelah menguji jarak minimal pada ketiga handphone android tersebut dan mendapatkan hasil bahwa jarak minimal untuk membaca object pada kamera handphone adalah $+10 \mathrm{~cm}$

\subsection{Hasil Pengujian Jarak Maximal}

Tabel 7. Hasil Pengujian Jarak Maximal

\begin{tabular}{lll}
\hline Perangkat & Versi Andorid & Jarak Maximal \\
\hline Samsung A7 2018 & $9.0($ Pie $)$ & $+110 \mathrm{Cm}$ \\
Oppo A9 2019 & $10.0(\mathrm{Q})$ & $+105 \mathrm{Cm}$ \\
Samsung A51 2020 & $11.0(\mathrm{R})$ & $+126 \mathrm{Cm}$ \\
\hline
\end{tabular}

Dalam pengujian jarak maximal yang telah dilakukan pada ketiga handphone andorid menunjukan bahwa samsung a7 2018 dengan versi andorid 9 membutuhkan jarak maximal $+110 \mathrm{~cm}$ supaya object terbaca oleh kamera handphone, sedangkan oppo a9 2019 dengan versi andorid 10 membutuhkan jarak $+105 \mathrm{~cm}$ supaya object terbaca oleh kamera handphone, dan samsung a51 2020 dengan versi 11 membutuhkan jarak $+126 \mathrm{~cm}$ supaya object terbaca oleh kamera handphone.

\subsection{Hasil Kemiringan Sudut}

Tabel 8. Hasil Kemeringan Sudut

\begin{tabular}{llll}
\hline Perangkat & $<18^{\circ}$ & $\begin{array}{l}\text { Keterangan } \\
20^{\circ}-60^{\circ}\end{array}$ & $61^{\circ}-90^{\circ}$ \\
\hline Samsung A7 2018 & Tidak Mendeteksi & Mendeteksi & Mendeteksi \\
Oppo A9 2019 & Tidak Mendeteksi & Mendeteksi & Mendeteksi \\
Samsung A51 2020 & Tidak Mendeteksi & Mendeteksi & Mendeteksi
\end{tabular}

Pada tabel 8 mendapatkan hasil pada saat sudut $<18^{\circ}$ ketiga handphone yaitu tidak mendeteksi, tetapi pada sudut 20-60 dan 61-90 ketiga handphone tersebut mendeteksi dan terbaca pada layar handphone

\section{KESIMPULAN}

Aplikasi ini dibuat sebagai media pengenalan tumbuhan dengan menggunakan teknologi augmented reality berbasis andorid

Dalam pengujian jarak miminal dan maximal yang sudah di lakukan terhadap tiga handphone tersebut, mendapatkan hasil bahwa samsung a7 2018 dengan versi andorid 9 membutuhkan jarak minimal $+10 \mathrm{~cm}$ dan jarak maximal $+110 \mathrm{~cm}$ supaya object terbaca oleh kamera handphone, sedangkan oppo a9 2019 dengan versi andorid 10 membutuhkan jarak minimal $+10 \mathrm{~cm}$ jarak maximal $+105 \mathrm{~cm}$ supaya object terbaca oleh kamera handphone, dan samsung a51 2020 dengan versi 11 membuthkan jarak minimal $+10 \mathrm{~cm}$ dan jarak maximal+126 cm supaya object terbaca oleh kamera handphone.

Saat pengujian kemiringan sudut pada 3 handphone yaitu samsung a7 2018, oppo a9 2019, samsung a51 2020, Mendapatkan hasil bahwa pada saat kemiringan $<18^{\circ}$ ketiga handphone tersebut tidak mendeteksi marker sedangkan saat pada sudut $20^{\circ}-60^{\circ}$ dan $61^{\circ}-90^{\circ}$ ketiga handphone tersebut dapat mendeteksi dan terbaca pada layar handphone 


\section{SARAN}

Perlunya teknologi yang lebih baru dari augmented reality yaitu seperti miexed reality atau extended reality,untuk membuat sebuah aplikasi yang lebih nyata lagi dan bisa berinteraksi dalam teknologi yang lebih terbaru atau bisa di sebut lebih cangih dari pada augmented reality.

\section{DAFTAR PUSTAKA}

[1] Khairuna, "Diktat Fisiologi Tumbuhan," Progr. Stud. Pendidik. Biol. Fak. Ilmu Tarb. dan Kegur. Univ. Islam Negeri Sumatera Utara, p. 124, 2019.

[2] S. Balandin, I. Oliver, S. Boldyrev, A. Smirnov, N. Shilov, and A. Kashevnik, "Multimedia services on top of M3 Smart Spaces," Proc. - 2010 IEEE Reg. 8 Int. Conf. Comput. Technol. Electr. Electron. Eng. Sib., vol. 13, no. 2, pp. 728-732, 2010, doi: 10.1109/SIBIRCON.2010.5555154.

[3] L. Hakim, "Pengembangan Media Pembelajaran Pai Berbasis Augmented Reality," Lentera Pendidik. J. Ilmu Tarb. dan Kegur., vol. 21, no. 1, pp. 59-72, 2018, doi: 10.24252/lp.2018v21n1i6.

[4] R. Efendi, "Rancang Bangun Aplikasi Augmented Reality Untuk Deteksi Pengenalan Tanaman Obat Berbasis Android," IKRA-ITH Inform., vol. 4, no. 1, pp. 35-45, 2020, [Online]. Available: rizalefendi248@gmail.com.

[5] G. Y. Abdillah, S. Andryana, and A. Iskandar, "Augmented Reality Sebagai Media Pembelajaran Perangkat Keras Komputer Dengan Fast Corner Dan Natural Feature Tracking," JIPI (Jurnal Ilm. Penelit. dan Pembelajaran Inform., vol. 5, no. 2, p. 79, 2020, doi: 10.29100/jipi.v5i2.1767.

[6] N. Wahyudi, R. A. Harianto, and E. Setyati, "Augmented Reality Marker Based Tracking Visualisasi Drawing 2D ke dalam Bentuk 3D dengan Metode FAST Corner Detection," J. Intell. Syst. Comput., vol. 1, no. 1, pp. 9-18, 2019, [Online]. Available: https://jurnal.istts.ac.id/index.php/INSYST/article/view/28.

[7] A. Ratnasari and E. Mulyanto, "Augmented Reality Struktur dan Fungsi Tumbuhan Sebagai Media Pembelajaran Berbasis Platform Android," J. IJCCS, no. x, pp. 1-16, 2017.

[8] L. Vinet and A. Zhedanov, "A 'missing' family of classical orthogonal polynomials," $J$. Phys. A Math. Theor., vol. 44, no. 8, pp. 1-8, 2011, doi: 10.1088/17518113/44/8/085201.

[9] A. Syahputra, S. Andryana, and A. Gunaryati, "Aplikasi Augmented Reality (AR) dengan Metode Marker Based sebagai Media Pengenalan Hewan Darat pada Anak Usia Dini menggunakan Algoritma Fast Corner Detection (FCD)," J. JTIK (Jurnal Teknol. Inf. dan Komunikasi), vol. 4, no. 2, p. 56, 2020, doi: 10.35870/jtik.v5i1.164. 
[10] R. Rumajar, A. Lumenta, B. A. Sugiarso, and J. T. E. Unsrat, "Perancangan Brosur Interaktif Berbasis Augmented Reality," Tek. Elektro dan Komput., vol. 4, no. 6, pp. 1-9, 2015.

[11] Dewi Agushinta Rahayu, Ihsan Jatnika, Henny Medyawati, Hustinawaty, 2017, "Implementasi Database Cloud Buah pada Vuforia," Prosiding Seminar Nasional Darmajaya, Vol.1, No.1, pp.502-512.

[12] D. A. Pangestu, F. Fauziah, and N. Hayati, 2020, "Augmented Reality Sebagai Media Edukasi Mengenai Lapisan Atmosfer Menggunakan Algoritma Fast Corner," JIPI (Jurnal Ilmiah Penelitian dan Pembelajaran Informatika) Vol.5 No.2, 67-78. 